\title{
DQw7 and the C4B null allele in rheumatoid arthritis and Felty's syndrome
}

\author{
R Clarkson, A S Bate, D M Grennan, C Chattopadhyay, P Sanders, M Davis, C Kelly
}

\begin{abstract}
$\mathrm{DQ} \beta$ and $\mathrm{C} 4$ null alleles have been defined in patients with rheumatoid arthritis, Felty's syndrome, and in control subjects. Comparison of DR4 positive subjects shows that rheumatoid disease without extra-articular features has no preferential associations with either DQB or C4 null variants. In Felty's syndrome there are significant associations with both the class II major histocompatibility complex (MHC) DQw7 allele (86\% of DR4 positive patients with Felty's syndrome and $53 \%$ of DR4 positive controls) and the class III MHC C4B null allele ( $50 \%$ of patients with Felty's syndrome and $20 \%$ of DR4 positive controls). DQw7 and the CAB null allele are in linkage disequilibrium and the B44-Bf *S-C4A*3-C4B*Q0-DR4-DQw7 haplotype accounts for five of 24 DR4 positive haplotypes assigned in subjects with Felty's syndrome. The results were not accounted for by articular disease severity and suggest that articular and extra-articular forms of rheumatoid disease may be immunogenetically heterogeneous.
\end{abstract}

The genetic predisposition to rheumatoid arthritis (RA) is poorly understood but partly accounted for by genes within the major histocompatibility complex (MHC). The MHC of man includes class I (HLA-A, B, and C), class II (DP, DQ, and DR), and class III regions (complement $\mathrm{C} 2, \mathrm{Bf}$, and the duplicated $\mathrm{C} 4$ loci, C4A and C4B). Silent or null alleles, associated with absence of the protein product, are found at both $\mathrm{C} 4$ loci. The main rheumatoid association is with the serologically defined, class II MHC variant, HLA-DR4. Recombination between DQ and DR loci is uncommon, and DR4 positive haplotypes may be either DQw7 or DQw8 positive according to DNA variation at the $D Q \beta$ locus, and where the DQw7 allele correlates with the serologically defined DQ 'Ta 10 ' specificity. ${ }^{1}$ In RA overall the relative risk for disease in subjects carrying the DR4 specificity is only increased fourfold and it is controversial whether there is preferential association at the DQ $\beta$ locus when DR4 matched RA and control subjects are studied. ${ }^{2}{ }^{3}$

Rheumatoid arthritis is clinically heterogeneous and the uncommon extra-articular subset of Felty's syndrome shows an almost absolute association with DR4. ${ }^{4}$ In studies of different patient groups Felty's syndrome has also been shown to have associations at the DQB locus with $\mathrm{DQw} 7^{56}$ and within the class III region with the $\mathrm{C} 4 \mathrm{~B}$ null allele. ${ }^{7}$ The biological significance of these associations is unknown and might represent the independent effects of two genes within the class II and III MHC regions respectively, or a primary association of either $D Q \beta$ or $C 4 B$ null variant with the other association being secondary, or both associations might be secondary to linkage disequilibrium with a single gene elsewhere in the MHC. We have attempted to distinguish between these possibilities by parallel studies of both $\mathrm{C} 4 \mathrm{~B}$ and $D Q \beta$ variants and their haplotypic associations in patients with RA with and without Felty's syndrome. The rheumatoid population without extra-articular features has previously been categorised as familial and non-familial and as small differences in the prevalence of DR4 antigens have been noted, ${ }^{8}$ these categories have been maintained in this study.

\section{Patients and methods}

SUBJECTS

All subjects were white and lived in the British Isles. Thirty four patients with Felty's syndrome were studied. Felty's syndrome was defined as classical RA plus splenomegaly reported by a clinician or ultrasound plus white cell count less than $3.5 \times 10^{9} / 1$ and granulocyte counts less than $2 \times 10^{9} / 1$ over periods of at least six months and not attributable to drug toxicity. The results of $\mathrm{C4}$ allotyping were reported previously in 20 of these subjects with Felty's syndrome. ${ }^{7}$ Two hundred and eighteen subjects with classical and definite $\mathrm{RA}^{9}$ and without the extra-articular features of Felty's syndrome or vasculitis were studied; 64 were probands of multiple case RA families and 154 were unrelated patients with $R A$ without a reported family history of the disease (sporadic RA). HLA-DR antigens were typed in all these subjects, DQ $\beta$ alleles in 69 DR4 positive subjects, C4 allotypes in 64 DR4 positive subjects, and both DQ $\beta$ and $C 4$ variants in 28 DR4 positive subjects. Eleven additional subjects with RA without extra-articular disease features were studied because they matched the first 11 subjects with Felty's syndrome for age, sex, and articular disease severity. One hundred and seventy four controls were studied; HLA-DR antigens were typed in all, DQ $\beta$ alleles were typed in $74 \mathrm{DR} 4$ positive subjects, $\mathrm{C4}$ allotypes in 74 subjects, and both $D Q \beta$ and $C 4$ variants in 22. Family material was available for identification of MHC haplotypes and as an aid to identification of $\mathrm{C4}$ allotypes for 54 subjects with familial RA, 24 with Felty's syndrome, 35 DR4 positive control subjects, and 39 DR4 negative control subjects. 


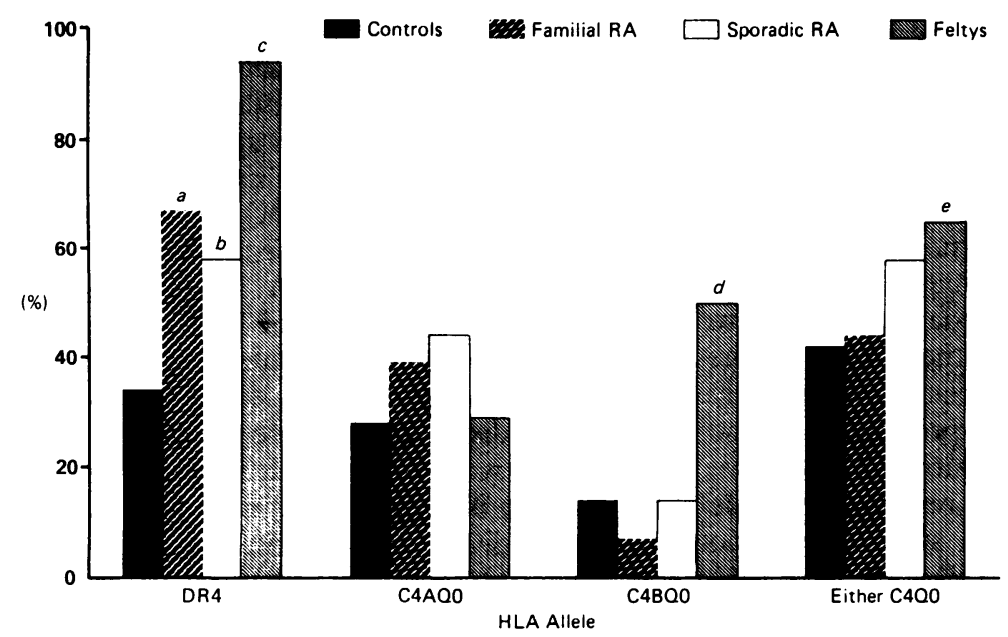

Figure 1 Percentage of patients with familial rheumatoid arthritis $(R A)$, sporadic $R A$, Felty's syndrome, and of control subjects typing for $H L A-D R 4$ and $C 4$ null alleles. $(a) \chi^{2}$, $p=1 \times 10^{-4}$ v controls; $(b) \chi^{2}, p=1 \times 10^{-4} v$ controls; $(c) \chi^{2}, p=1 \times 10^{-4} v$ controls; $\chi^{2}$, $p=6 \times 10^{-3}$ v familial $R A ;(d) \chi^{2}, p=2 \times 10^{-4}$ v controls; $\chi^{2} p=1 \times 10^{-4}$ v familial $R A ; \chi^{2}$, $p=9 \times 10^{-4} v$ sporadic $R A ;(e) \chi^{2}, p=0.06 v$ familial $R A ; \chi^{2}, p=0.03 v$ controls.

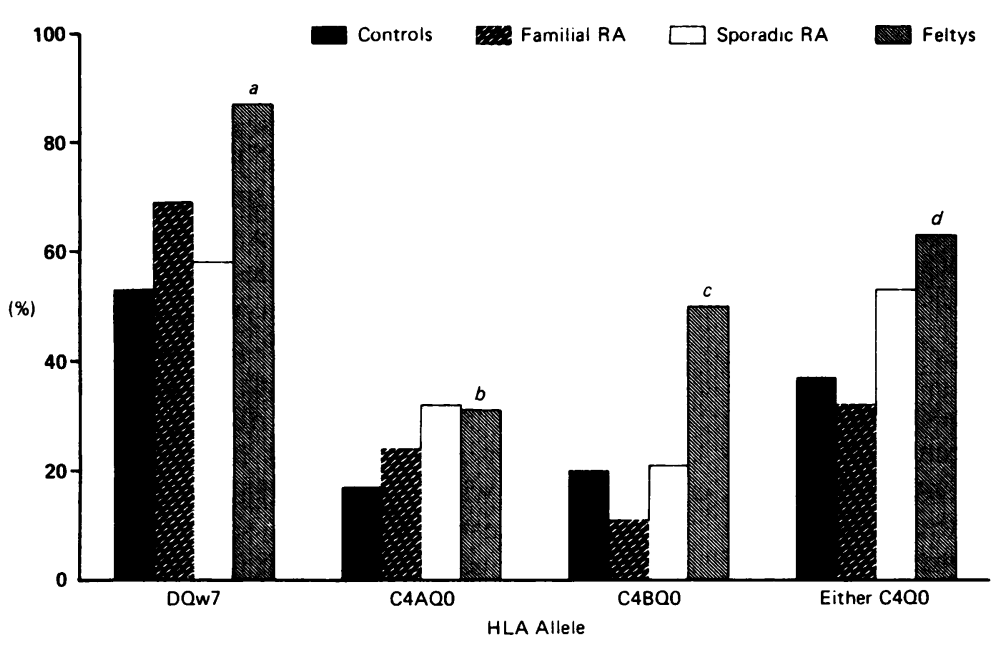

Figure 2 Percentage of DR4 positive patients with familial rheumatoid arthritis $(R A)$, sporadic $R A, F$ elty's syndrome, and of control subjects typing for $H L A-D Q w 7$ and $C 4$ null alleles. (a) $\chi^{2}, p=3 \times 10^{-3} v$ controls, Fisher's, $p=8 \times 10^{-3}$ v sporadic $R A$, Fisher's, $p=0.092$ v familial $R A,(b)$ Fisher's, $p=0.093$ v controls, (c) Fisher's, $p=7.6 \times 10^{-3} v$ controls, Fisher's, $p=3 \times 10^{-4}$ v familial $R A$, Fisher's, $p=9 \cdot 3 \times 10^{-3}$ v sporadic $R A ;(d)$ Fisher's, $p=0.019 v$ controls, Fisher's, $p=8 \cdot 9 \times 10^{-3} v$ familial $R A$.

HLA-DR4 positive haplotypes in patients with Felty's syndrome

\begin{tabular}{|c|c|c|c|c|c|c|}
\hline$H L A-B$ & $B f$ & $C 4 A$ & $C 4 B$ & $H L A-D R$ & $H L A-D Q B$ & $\begin{array}{l}\text { No } \\
(n=24)\end{array}$ \\
\hline $\begin{array}{c}44 \\
44 \\
40 \\
40 \\
40 \\
62 \\
62 \\
62 \\
8 \\
8 \\
8 \\
8 \\
8 \\
7 \\
7 \\
35 \\
27 \\
\text { w70 } \\
45\end{array}$ & $\begin{array}{l}\mathbf{S} \\
\mathbf{S} \\
\mathrm{F} \\
\mathbf{S} \\
\mathbf{S} \\
\mathbf{S} \\
\mathbf{S} \\
\mathbf{S} \\
\mathbf{S} \\
\mathbf{S} \\
\mathbf{S} \\
\mathbf{S} \\
\mathbf{S} \\
\mathbf{S} \\
\mathbf{S} \\
\mathbf{S} \\
\mathbf{S} \\
\mathbf{S}\end{array}$ & $\begin{array}{l}3 \\
3 \\
3 \\
3 \\
2 \\
3 \\
4 \\
3 \\
0 \\
3 \\
3 \\
3 \\
3 \\
3 \\
3 \\
3 \\
3 \\
3 \\
3\end{array}$ & $\begin{array}{l}0 \\
1 \\
1 \\
0 \\
2 \\
3 \\
2 \\
0 \\
1 \\
1 \\
0 \\
1 \\
3 \\
0 \\
1 \\
1 \\
1 \\
1 \\
0\end{array}$ & $\begin{array}{l}4 \\
4 \\
4 \\
4 \\
4 \\
4 \\
4 \\
4 \\
4 \\
4 \\
4 \\
4 \\
4 \\
4 \\
4 \\
4 \\
4 \\
4 \\
4\end{array}$ & $\begin{array}{l}\text { DQw7 } \\
\text { DQw2 } \\
\text { DQw8 } \\
\text { DQw7 } \\
\text { DQw7 } \\
\text { DQw8 } \\
\text { DQw8 } \\
\text { DQw5 } \\
\text { DQw7 } \\
\text { DQw2 } \\
\text { DQw7 } \\
\text { DQw7 } \\
\text { DQw7 } \\
\text { DQw7 } \\
\text { DQw7 } \\
\text { DQw8 } \\
\text { DQw8 } \\
\text { DQw7 } \\
\text { DQw7 }\end{array}$ & $\begin{array}{l}5 \\
1 \\
1 \\
1 \\
1 \\
1 \\
1 \\
1 \\
1 \\
1 \\
2 \\
1 \\
1 \\
1 \\
1 \\
1 \\
1 \\
1\end{array}$ \\
\hline
\end{tabular}

LABORATORY METHODS

$D Q \beta$ alleles were defined on the basis of restriction fragment length polymorphisms obtained by hybridisation of a DQ $\beta$ DNA probe to Taq I digests of DNA extracted from circulating white cells. ${ }^{10} \mathrm{C} 4$ allotypes were defined by agarose gel electrophoresis of neuraminidase and carboxypeptidase $B$ digested plasma or serum samples followed by immunofixation with antiserum to $C 4$. $^{11}$

HLA-A, B, and DR antigens were typed by standard techniques using antisera characterised by a cell panel that was typed with 9 th and 10th histocompatibility workshop antisera.

\section{STATISTICS}

Statistical significances of differences in marker frequencies between groups were analysed by $\chi^{2}$ or Fisher's test. ${ }^{12}$ Delta $(\Delta)$ values were used to express the strength of linkage disequilibrium between alleles at different loci. ${ }^{13}$ The simple empirical logistic method was used to determine which of the two associations with Felty's syndrome might be primary where there was known linkage disequilibrium between the two markers. ${ }^{14}$

\section{Results}

As expected, the HLA-DR4 antigen was found more commonly in all rheumatoid groups, with $94 \%$ of patients with Felty's syndrome, $67 \%$ of those with familial $\mathrm{RA}$, and $58 \%$ of patients with sporadic RA typing for this antigen compared with $34 \%$ of controls (fig 1 ). The DQw7 allele was found in $53 \%$ of DR4 positive controls, $58 \%$ of DR4 positive sporadic RA, and in $69 \%$ of DR4 positive familial subjects with RA (differences not statistically significant). There were no significant increases in C4 null allele frequencies in familial and sporadic RA groups, though there was a trend for the C4A null allele to be increased in the sporadic RA group and for a slight decrease in the C4B null allele in the familial RA group as previously reported. ${ }^{7}$

In the subjects with Felty's syndrome the C4B null allele was more prevalent than in $R A$ or control subjects (fig 1), and these differences remained when DR4 positive subjects only (fig 2) were considered (DR4 and the C4B null allele are in linkage disequilibrium). The number of subjects with Felty's syndrome typing for either a $\mathrm{C4A}$ or $\mathrm{CAB}$ null allele was also increased, but this was mainly accounted for by the increased prevalence of the C4B null allele. The DQw7 allele was also more prevalent in DR4 positive patients with Felty's syndrome than in DR4 positive controls.

Thus the prevalence of both the C4B null and the DQw7 alleles was increased in the group with Felty's syndrome. Within the total population studied there was significant linkage disequilibrium between $\mathrm{DQw} 7$ and the C4B null allele (total number of established haplotypes $\left.=147 ; \Delta=0.037, \chi^{2}=5.84 ; \quad p=0.015\right)$. Within the group with Felty's syndrome 24 DR4 positive haplotypes (table) were assigned in 21 subjects. The most prevalent haplotype in 
those with Felty's syndrome was the haplotype HLA-B44-Bf*S-C4A*3-C4B*Q Q-DR4-DQw7 which accounted for five of the 24 DR4 positive haplotypes assigned in those with Felty's syndrome. Haplotypes were assigned in four subjects positive and heterozygous for both markers and in one of these subjects the C4B null allele and DQw7 were on opposite haplotypes (trans).

By simple subdivision of data according to the presence or absence of either DQw7 or the C4B null allele neither association was clearly secondary to the other as the prevalences of the C4B null allele in subjects positive and negative for $D Q w 7$ were $52 \%$ and $40 \%$ respectively while the prevalences of $\mathrm{DQw} 7$ in subjects who do and do not type for a C4B null allele were $88 \%$ and $82 \%$ respectively. The empirical logistic method has been used previously to try to determine which of two associations with a disease may be primary where two markers are in linkage disequilibrium. ${ }^{14}$ In our study the empirical logistic analysis suggested that the $\mathrm{DQw7}$ association is more likely to be primary $(p=0.014)$ than the C4B null allele association $(p=0.3)$ or the combined effect of both markers $(\mathrm{p}=0.69)$.

Eleven further subjects with RA without extra-articular features were chosen as a match for the first 11 subjects with Felty's syndrome on the basis of age, sex, disease duration, and articular disease severity (radiological). In this small group the prevalence of the $\mathrm{C} 4 \mathrm{~B}$ null allele was $27 \%$ and only three of the seven DR4 positive subjects typed for $\mathrm{DQw}$.

\section{Discussion}

These results confirm the associations within DR4 positive subjects between Felty's syndrome and both $\mathrm{DQw} 7$ and $\mathrm{C} 4 \mathrm{~B}$ null alleles, which are studied together for the first time in a group of subjects with Felty's syndrome. DQw7 and $\mathrm{C} 4 \mathrm{~B}$ null allele prevalences are not increased in subjects with RA without extra-articular disease features so that $\mathrm{DQw} 7$ and $\mathrm{C} 4 \mathrm{~B}$ null alleles seem to be markers within the rheumatoid population for those at risk of developing the extra-articular features of Felty's syndrome. We cannot account for these associations simply on the grounds of articular disease severity as in a small group of subjects with RA matched for articular disease severity, no trend for a similar effect is seen.

The main HLA association for rheumatoid disease regardless of extra-articular disease features has been with HLA-DR4. DR alleles associated with susceptibility to $R A$ share a common amino acid sequence at residues 70-72 in the third hypervariable region of the DRB1 gene and this sequence has been proposed as the molecular basis for the HLA association with RA. ${ }^{15}$ It would be of interest to examine the DRB1 encoded Dw subtypes of DR4 in subjects with Felty's syndrome, though on present evidence the DQw7 and C4B null associations described seem likely to indicate an effect of genes outside the DRB1 locus on disease expression. The associations with these alleles in Felty's syndrome might represent an independent effect of two genes within class II and
III regions respectively, or a primary association of either DQw7 or C4B null alleles with the other association being secondary, or both genes might be secondary to linkage disequilibrium with a single gene elsewhere in the MHC. In the total population studied $\mathrm{DQw} 7$ and the $\mathrm{C} 4 \mathrm{~B}$ null allele are in linkage disequilibrium and the haplotype $B 44-B^{*} S-C 4 A^{*} 3-C 4 B^{*} Q 0-D R 4$ DQw7 accounts for five of 24 DR4 positive haplotypes ascertained in subjects with Felty's syndrome. In this situation where two markers in linkage disequilibrium are associated with a disease it is often difficult to define which association, if either, is primary. In this study simple subdivision of the data according to the presence and absence of either marker does not show either effect as clearly secondary. The empirical logistic method has been used previously to investigate which of two markers may have a primary association with a disease after allowing for allelic association between the two markers. ${ }^{14}$ Application of this analysis suggests that the $D Q \beta$ association is more likely to be primary than the C4B null allele association. Numbers of subjects tested are limited, however, so that these results should be interpreted with caution and do not definitely exclude the possibilities that both associations might be secondary to the effect of a gene elsewhere in the MHC or might represent an effect of separate genes within class II and class III regions respectively. This latter possibility is supported by the finding of a trans association of DQw7 and C4B null alleles in one of only four subjects with Felty's syndrome positive and heterozygous for both markers and in whom haplotypes have been ascertained. A direct effect for the C4B deficiency is also supported by the variety of molecular mechanisms from which a C4B null allele may arise. ${ }^{16}$ One mechanism by which a separate class III effect might occur is through a direct effect of the partial C4B deficiency itself. Circulating immune complexes may contribute to the pathogenesis of Felty's syndrome ${ }^{17}$ and as classical complement pathway components have an important role in preventing precipitation of immune complexes ${ }^{18}$ this is one way in which partial C4 deficiency might be involved.

Thus these studies have shown that Felty's syndrome has an association with DQw7 and C4B null alleles, which are in linkage disequilibrium on a haplotype bearing DR4. Studies of class II and III MHC variants in other extraarticular rheumatoid disease subsets would be of interest.

Financial support from the Arthritis and Rheumatism Council (ARC) is gratefully acknowledged. We are indebted to the following doctors who contributed patients to the studies: $\mathbf{R}$ Bernstein, M Burke, R Hilton, L Holt, E Hothersall, $M$ Jayson E Smith, P Smith, D Swinson. We are grateful to Dr J Silver of the Mount Sinai School of Medicine for providing the DOB probe. Tissue typing for HLA-DR antigens was by courtesy of Dr P Dyer of the tissue typing department of St Mary's Hospital, Manchester.

1 Radka S F, Scott R G, Stewart S J. Molecular complexity of HLA-DQw3: the Talo determinant is located on a subset of DRw3 B chains. Huen Immanol 1987; 18: 287-300.

2 Singal D P, Reid B, Kassam Y B, Souza M, Bensen W G Adachi J D. HLA-DQ beta-chain polymorphism in HLADR4 haplotypes associated with rheumatoid arthritis. Lancet 1987; ii: 1118-9.

3 Nepom G T, Hansen J A, Nepom B S. The molecular basis for HLA class II associations with rheumatoid arthritis. f Clin Immunol 1987; 7: 1-7. 
4 Westedt M L, Breedveld F C, Schreuder G M, D'Amoro J D, Cats A, De Vries R R P. Immunogenetic heterogeneity of rheumatoid arthritis. Ann Rhewm Dis 1986; 45: 534-8.

5 So A K S, Warner C A, Sansom D, Walport M J. DQB polymorphism and genetic susceptibility to Felty's synpolymorphism and genetic susceptibility

6 Sansom D M, Bidwell J L, Maddison P J, Campion G, Klouda D T, Bradley B A. HLA DQ alpha and DQ beta restriction fragment length polymorphisms associated with Felty's syndrome and DR4-positive rheumatoid arthritis. Hum Imemenol 1987; 19: 269-79.

7 Thomson W, Sanders P A, Davis M, Davidson J, Dyer P A Grennan D M. Complement C4B-null alleles in Felty's syndrome. Arthritis Rhewn 1988; 31: 984-9.

8 Sanders P A, Grennan D M, Dyer P A, Thomson W, De Lange G. A comparison of clinical and immunogenetic features in familial and sporadic theumatoid arthritis. $\mathcal{J}$ Rhewematol 1987; 14: 718-22.

9 Ropes M W. Diagnostic criteria for rheumatoid arthritis. 1958 revision. Ann Rhewen Dis 1959; 18: 49-53.

10 Bidwell J L, Bidwell E A, Savage D A, Middleton D, Klouda P T, Bradley B A. A DNA-RFLP typing system that positively identifies serologically well-defined and illdefined HLA-DR and DQ alleles, including DRw10. Transplantation 1988; 45: 640-6.
11 Sim E, Cross S J. Phenotyping of human complement component C4, a class-III HLA antigen. Biochem $\mathcal{F}$ 1986; 239: 763-7.

12 Siegel S. Nom-parametric statistics for the behavioural sciences. New York: McGraw-Hill, 1956

13 Mathews I D. HLA genetics. In: Simons M H, Tait B D eds. Detection of immane-associated genetic markers of human eds. Detection of immane-associated genetic markers of hwoman 14 Green J R, Chiew M, Low H, Woodrow J. The association between HLA antigens and the presence of certain diseases. Stat Med 1983; 2: $79-85$.

15 Gregersen P, Silver J, Winchester R. The shared epitope hypothesis. An approach to understanding the molecular genetics of susceptibility to rheumatoid arthritis. Arthritis Rheven 1987; 30: 1205-13.

16 Hillarby M C, Strachan T, Grennan D M. Molecular characterisation of $\mathrm{C} 4$ null alleles found in Felty's syndrome. Ann Rhewen Dis 1990; 49: 763-7.

17 Breedveld F C, Lafeber G J M, Doeker G, Claus F, Cats A Felty's syndrome: autoimmune neutropenia or immuneFeity's syndrome: autoimmune neutropenia or immune-

18 Naama J K, Mitchell W, Zoma A, Veitch J, Whaley $K$ Complement-mediated inhibition of immune precipitation in patients with immune complex disease. Clin Exp Imimanol 1983; 51: 292-8. 